\title{
Poverty and the Poor in the Early Church: A Challenge to Prosperity Preachers in Nigeria
}

\author{
1PhD. David Ononogbu \\ Department of Religion and Cultural Studies, University of Nigeria, Nsukka \\ david.ononogbu@unn.edu.ng
}

\section{Emmanuel Chiwetalu Ossai}

Department of Religion and Cultural Studies, University of Nigeria, Nsukka Emmanuel.ossai@unn.edu.ng

${ }^{3}$ George Christian Nche

Department of Religion and Cultural Studies, University of Nigeria, Nsukka, Corresponding Author nche.george@unn.edu.ng

\section{PhD. Christopher N. Ibenwa}

\author{
Department of Religion and Cultural Studies, University of Nigeria, Nsukka
} christopher.ibenwa@unn.edu.ng

Doi:10.5901/mjss.2016.v7n5p377

\begin{abstract}
This study compared the early church's conceptualization of poverty, and attitude towards the poor, with that of the contemporary Prosperity Preachers in Nigeria. Hermeneutical and comparative phenomenological methodologies were employed. The study revealed that in the early church, the majority of the members were poor, yet there was no practice which involved the elements of modern 'prosperity preaching' in Nigeria. In fact, the early church had a view of poverty and disposition towards the poor that is different from that of the prosperity preachers in Nigeria. This served as a justification for the position of the study on the prosperity preaching movement.
\end{abstract}

Keywords: Poverty, Poor, Early church, Prosperity preaching, Material wealth

\section{Introduction}

The concept of economic prosperity is a controversial subject which has drawn much attention among Christian theologians in recent times. Prosperity preaching, also called prosperity gospel, is a movement which holds that a Christian is by nature, meant to be rich and that poverty is ungodly (Onwu, 2007; Lioy, 2007; Folarin, 2006). It also holds that a poor Christian is under satanic curse (Celestina, 2007). It arose in Nigeria between late 1970s and early 1980s. In the midst of widespread poverty and perceived governmental incapability and distrust, religion has become an institution where Nigerians search for succor and seek solutions, and with the promise of health and wealth, the prosperity gospel has gained acceptance among a substantial percentage of Nigerians. One of the disturbing aspects of the gospel with which this study is concerned is its religious and apparently simplistic view of a multidimensional factor such as 'poverty' which currently plagues Nigeria.

Poverty is a multifarious factor which can be measured by several parameters such as health, nutrition, education, assets, housing, income or possession of certain rights (Worldbank 2005). It is however basically a condition of having insufficient resources or income, (Corbett, 2009). According to a 2010 Harmonized Nigeria Living Standard Survey done by the National Bureau of Statistics (NBS), 70 percent of Nigerians live in poverty; only 30 percent crossed the poverty line (NBS 2010). It thus, seems that this situation is directly linked to the prosperity preaching phenomenon in Nigeria.

Similar to the contemporary Nigerian Christian church, there was in the early church, social stratification, where some were wealthier than others, and some indigent. It was this situation that necessitated charity in the early church. There can be no charity in the absence of poverty. It can also be rightly said that it was probably because of the presence 
of poverty and the poor in the early church, that the issue of poverty and wealth, was a major concern in earliest Christianity (Onwu, 2004). Poverty and wealth are among the most emphasized subjects in the New Testament. This partly provides a basis for this research. Arguably, Prosperity Preaching has become the most popular approach to wealth and poverty in within Pentecostal churches in Nigeria. In a country where about 70 percent of citizens are poor; where unemployment rate has continued to grow; and where citizens have little or no hope on the government for a lasting solution; the prosperity preachers expectedly continue to gain wide acceptance and flourish like flowers. Having "presented themselves, through their activities, to be capable therapists to the neurotic conditions in which many Nigerians now find themselves,"(Celestina, 2007 p.285) these preachers maintain wide and continuously growing influence among Christians in Nigeria. Poverty, the gospel says, is ungodly, and an experience which a Christian or child of God should not have, for God wills that His children be wealthy and comfortable. In fact, poverty results from satanic or demonic influence.

The study, therefore, examines the economic circumstances within and around the early church of the New Testament text, the early Christians' understanding of poverty, and the church's attitude towards her poor members; so as to compare the past with the present prosperity preaching phenomenon in Nigeria. Even though the early Christians did not question God's boundless goodwill for Christians, poverty was not regarded as an offshoot of sin, satanic influence, or ungodly. The early church did not also teach that God finds pleasure in the poverty of believers. Yet, material prosperity was not regarded as the main medium by which God's love and blessing is expressed. There was poverty within that church; there was poverty around that church; and yet, there was no such prosperity ideology as is in the present time. If poverty was observed in the early Church, and yet those Christians were not seen as people under satanic curses, how could poverty among Christians in Nigeria become a curse?

It is needful to state that this study does not reject the prosperity gospel in its entirety as it is not merely material, but involves both spiritual, economic and physical prosperity and wellbeing (Onwu 2007). The point of concentration, however, is the prosperity preachers' overemphasis and prioritization of material prosperity over more cardinal Christian values such as righteousness and contentment which appears to be at the heart of the Early Church's life. The study also criticized the prosperity preachers' simplistic view of poverty which is evidently a multidimensional factor.

\section{Methodology}

As a qualitative study, the researchers relied on Documentary method of data collection which involved the use of Journal articles, Biblical Commentaries, periodicals, etc, whereas the hermeneutical and comparative phenomenological methodologies were adopted for analytical purposes. The former was used mainly in the New Testament study of the life of the early church. "Hermeneutics", according to Ituma (2011) "is often expressed in the phrase with exegesis since it has to examine the historical context of a text or biblical concept so as to apply it in modern understanding. Exegesis is the effort to understand the original meaning of a text or biblical concept as it was applied to the original audience. The research therefore involved the use of the New Testament in its original form (rendered in ancient Greek and Aramaic language) with explanations. With the comparative phenomenological method, the phenomenon of prosperity preaching in Nigeria was examined and compared with the early church's understanding and attitude towards the poor.

\section{The Prosperity Gospel}

Prosperity is the state or process of succeeding, flourishing, thriving, attainment of desire and possession of economic success. It often encompasses wealth but also includes other factors which are independent of wealth to varying degrees, such as happiness and health. Many distinct notions of prosperity such as economic wellbeing, health and happiness, are correlated or even have causal effects on one another. Prosperity Gospel, also called Prosperity Preaching, is a movement which has become popular in Africa, America and Europe. The exponents of this gospel in these separate places do not preach utterly the same thing, but some concepts and thought patterns form the key features of the gospel wherever it is being preached. These include faith, positive confession, and the concept that a Christian, by nature, is meant to be rich and that poverty is ungodly (Onwu, 2007; Lioy, 2007; Folarin, 2006) "Adherents insist that faith is a supernatural force that believers use to get whatever form of personal success they want, including physical health and material wealth" (Lioy, 2007 p.44). This faith is utilized with positive confession, by Christians, to obtain the longings of their heart. There is, according to Lioy (2007) "an implicit confidence in the power of positive confession, in which faith enables what believers think and say to become actualized realities"(p.44). These two, among others, would enable a believer to claim their unclaimed due, usually material prosperity.

Poverty and riches or related terms are the commonly used terms by the preachers. While the former should be 
dismissed immediately through their (the preachers') recommended means, the latter has to be actively invited and anticipated because it is God's will for believers. Part of the central basis for this ideology is the doctrine of atonement. According to them, poverty is part of the curse of the law or consequences of sin which Jesus dealt with by his death, so believers can enjoy all possible riches (Onwu, 2007; Folarin, 2006). How peculiar is the Nigerian version?

\section{How it is in Nigeria}

Expectedly, the phenomenon in Nigeria involves the above outlined concepts and ideologies, and probably has other peculiar features. In Nigeria, the exponents preach that "poverty and other vicissitudes of life are a form of oppression which manifest from the kingdom of darkness, from which Christians must seek to be delivered, in order to secure relief" (Celestina, 2007 p.284). Poverty and ill health are said to result from satanic or demonic influence, hence, a religious approach to them is recommended by the preachers. They are "propelled by the claim that God's will for all believers is for them to be rich materially, be overcomers and to be on top and not at the bottom in every human endeavor" (Celestina, 2007 p.287). For instance, E. A. Adeboye, a frontline exponent of the gospel, had promised in a revival that "there will be no more sickness...there will be no more failure...I have heard God speak and I can tell you, I have heard the sound of abundance" (www.nigeriavillagesquare.com). Such affirmations are common in sermons of these pastors. The preachers claim to be God's endowed media for the causation of miraculous improvements in believers' socioeconomic conditions. They appear "to be capable therapists to the neurotic conditions in which many Nigerians now find themselves." (Celestina, 2007 p.285). Chris Oyakhilome, one of Nigeria's foremost Pentecostal pastors and prosperity exponents once stated the following: "I have a message that certainly heals people. You cannot hear that message and remain sick, poor or dejected. It would bring you hope and life." (Ukah, 2007 p.4).

\subsection{Faith + Positive Confession + Giving/Tithing = Zero Poverty}

Following the said conviction, these exponents encourage their adherents to use faith, positive confession about their conditions, and other actions such as steady payment of tithes and donation to the church (usually called House of God), to liberate themselves from the oppression of poverty and ill health. Benson Idahosa, who is acknowledged to be the father of prosperity preaching in Nigeria once remarked that "There are no bounds that faith cannot break, no fetter it cannot sever, no dungeon it cannot open, no disease it cannot heal, no victory it cannot win"(Emeka, 2002 p.25). Similarly, David Oyedepo, another prominent preacher, argues that "A major law in the kingdom is according to your faith, be it unto you. In everything you do in the kingdom, your result is dependent on the measure of faith you have." (Oyedepo, 1992 p.76).

However, faith and giving (usually to the church) are taught to be equally important, as one cannot cause prosperity without the other. This probably explains why some Nigerian believers have given to their churches even when they could hardly afford it (The authors conducted an interview of a cross section of believers from three Pentecostal churches whose general overseers are exponents of the prosperity gospel). They directly associate financial prosperity and with giving; tithes must be regularly paid to the church in order to experience financial breakthroughs. When asked Why?, it is replied that, as recorded in Malachi 3:8-10, God opens the windows of heaven for those who bring their full tithes unto the Lord; and Jesus has instructed believers, according to Luke 6:38, to give so that it will be given unto them; and has confirmed too that the measure one gives will be the measure one gets back. While some of these preachers emphasize the importance of steady payment of tithes for financial prosperity some others prioritize it to the point of directly linking it to gaining access to paradise (Diara, 2011). Enoch Adeboye, a prominent Prosperity preacher in Nigeria, had declared that- "You do not pay your tithe; you do not go to heaven." (Adeboye, 2014 p.25). In his book The Son of Perdition, he refers to those who do not bring forth their tithes as "Children of Perdition" who will end up in the house of the devil where there is a great deal of fire and suffering (Adeboye, 2014).

Consequently, the delusion created by these preachers in the minds of the believers possibly explains the unconditional financial support of Pentecostal ministries by these believers even when there is obviously no appreciable or concrete achievement to accompany their gestures" (Celestina, 2007 p.288). The preachers obviously benefit largely from the financial returns from adherents as many of them live flamboyantly with private jets in the face of poor socioeconomic conditions of multitude of their congregations. As a result of its somewhat controversial nature and wide presence in Nigeria, the prosperity gospel has become a common issue in academic discourses. This study peculiarly contributes to these discourses by examining the socio-economic condition of the early church, its ideology about poverty and prosperity, attitude towards the poor; in order to ascertain the essence of the contemporary prosperity gospel movement in Nigeria. 


\section{Which is the Early Church?}

It is popular to refer to a particular building set aside for public worship by Christians, as church, even though the church means more than a building. Explaining this, Tony (1994) writes that:

The church is certainly not just a building, but the one thing Christians of all denominations and in all ages have done together is meet for public worship. This is so fundamental that any organization that did not conduct public worship would not be seen by anyone as a church. In fact, going to church means going to public worship-even if this happens to take place in a school hall (p.351).

Indeed, "church" refers to humans, people, not a building with sections such as the sanctuary and the nave. The word "church" is a German word Kircke or kirk rooted in the Greek word, Kyriake meaning the "house of God", which is also synonymous with another Greek word Kyriakon meaning the "house of the master" (Schamna, cited in Onimttawo 2007 p.115). The derivation of the word has been much debated. It is now agreed that it is derived from the Greek Kyriakon, that is "the Lord's house", a term which from the third century was used as well as ekklesia, to signify a Christian place of worship (Joyce, 1908). According to Price (2008) the most common word for church in the New Testament Greek is ekklesia, meaning "assembly". The Greek word, which came to mean church, was originally applied in the classical period to an official assembly of citizens. It was also used in the Old Testament.

In the Septuagint (Greek) translation of the Old Testament, the word is used for the general assembly of the Jewish people, especially when gathered for a religious purpose such as hearing the law (example Deuteronomy 9:10,18:16) (Encyclopedia Britannica 2009). In the New Testament, it is used for the entire body of believing Christians throughout the world (example Matthew 16:18), of the believers in a particular area (example Acts 5:11), and also of the congregation meeting in a particular house the "house church" (example Romans 16:5) (Encyclopedia Britannica 2009). In the same New Testament, according to Onimttawo (2007) the church was "an assembly of persons, which has been summoned for a particular purpose (Acts 19: 4-5,19,28,34-35; Colossians 4:16), as a community of believers which has been gathered from the inhabitants of a specific area, (Rom. 16:5; Col 4:15, Philemon 2; Rom 16:1; Col 4:15; Rom 16:1; Acts 8:1, Gal 1:2; 1 Cor. 16:19; Rev 1:4, 11), as a community gathered by God through Christ (Acts 20:28, 1 Cor. 1:2; 10:32, 11:16,22; 15:9: II Cor. 1:1; Gal1:13; 1Thess 2:14;11 Thess1:4; 1Tim 3:5,15), as the eschatological people of God (Eph.1:23; 2:10: 3:8-12; Col1: 21-27; Heb. 12:22-24; Rev. 1:29)" (p.155). Furthermore, the word ekklesia did not have only one meaning, use and application in the New Testament. It was used as an assembly of persons summoned for a particular purpose; a Community of believers which has been gathered from the inhabitants of a specific area; a community gathered by God through Christ, and as the eschatological people of God.

For the purpose of this study, however, the church consists of all those who adhere to the Christian religion. The early church is specifically the group of Christians who existed shortly after the death of Jesus in the first century AD. These Christians include the apostles who wrote the New Testament books (such as Paul and Mark) and the Christians whose collective and individual activities were recorded in the New Testament texts. This study refers to these Christians as the Early Church or the Church of the New Testament Era.

\section{Poverty Around the Early Church}

Were there poor people outside and around the early church? In other words, what was the economic condition of the society in which the church of the New Testament era existed? The New Testament era was a society influenced by Hellenistic ideas, customs, religion and language, but dominated by Roman law, governmental forms, ideas and the military (James, n.d) Rome was then the center of a vast and powerful empire that spanned from Britain, throughout southern and central Europe, northern Africa, and deep into the middle east, measuring about 3,000 miles/4,900 kilometers east to west and 2,000 miles/3,200 kilometers north to south. This Roman world, write Margaret and Robin, "was pre-industrial, its economy was fundamentally based in agriculture, and its population was largely rural" (Margaret and Robin, 2006 p.4). The "Roman economy was underdeveloped" (Margaret and Robin, 2006 p.4). This would be the economy's description in modern terms.

Poverty in the Roman world, according to Scheidel, in Margaret and Robin, was largely determined by access to land as "Those who owned, or were able to secure the rental of land could secure their subsistence provided that the area of land at their disposal was large enough and the climatic conditions favourable enough" (Margaret and Robin, 2006 p.4). The poor population in the first century Palestinian world would include everyone from small land owners, tenant farmers, and traders such as fishermen and carpenters down to those who owned no land, did not possess artistic 
skills or were even slaves or beggars (Davids, 2006). A good majority of the population lived in poverty. The "rich group" was made up of a little minority. This minority had more access to the state's resources. The empire concentrated more than half of the total wealth of all its subjects in the top or 2 percent of its populace (Guthrie, 2010). This class included the emperor and his court, other key political and military leaders, the landed aristocracy, and at times the most influential religious leaders. The ranks of the rich was heightened by the bureaucracy necessary to serve them nationally and locally (Guthrie, 2010). There also existed a small middle class made up of many priests and Pharisees, merchants and traders, artisans and craftsmen, bankers and tax collectors. They "earned enough to have modest savings and not live a merely day-to-day existence (and) comprised at most... 15 percent" (Guthrie, 2010 p.5). The third class is the class of the poor which consisted of over half of the total population. According to Guthrie (2010):

Up to 70 percent of the population consisted of struggling farmers and fishermen or subsistence laborers working for others in fields or factories. A denarius was a standard day's wage (see Matt 20:2) and enabled a laborer to buy food for himself and his family for the day with a little left over. Hired hands resembled modern migrant workers; their employment was seasonal. Any surplus they received had to be carefully saved. By any modern standards these 70 percent lived in poverty (p.6).

A last group of those who lived in a situation which could be referred to with the modern term extreme poverty made up about 10 percent. It included outcasts and expendables, who were often below even the subsistence level, with starvation a real threat (Guthrie, 2010). Expectedly, if there was a prosperity gospel movement, it would thrive in some parts of this empire, just as it does in Nigeria mainly due to harsh socio-economic conditions in the society. What is the poverty profile of Nigeria?

\section{Nigeria: Just Like that Empire}

Similar to the above situation in the Roman Empire of the New Testament era, is the present socio-economic state of Nigeria- a country of 36 states and a Federal Capital Territory, Abuja. It is hardly arguable that the present ill socioeconomic situation of the country has created a field of opportunities for the prosperity preachers. Unlike the New Testament era where a denarius was a standard day's wage (see Matt. 20:2), which could be used alongside access to land for measuring poverty and wealth; modern times commonly use the $\$ 1$ and $\$ 2$ per day measure, access to social services and basic amenities, among others.

In 2010, the National Bureau of Statistics used a measure which it called Relative Poverty Measurement. The major component in the computation of this measure is the household expenditure, which refers to all goods and services for use in the household, and also all monetary transactions of the household such as donations and savings (National Bureau of Statistics, 2010). Below is a poverty headcount from 1980-2010 by the National Bureau of Statistics based on the said measure.

Table 1: Showing Relative Poverty Headcount from 1980-2010

\begin{tabular}{|c|c|c|c|}
\hline Year & Poverty Incidence (\%) & Estimated Population (Million) & Population in poverty (Million) \\
\hline 1980 & 27.2 & 65 & 17.1 \\
\hline 1985 & 46.3 & 75 & 34.7 \\
\hline 1992 & 42.7 & 91.5 & 39.2 \\
\hline 1996 & 65.6 & 102.3 & 67.1 \\
\hline 2004 & 54.4 & 126.3 & 68.7 \\
\hline 2010 & 69.0 & 163 & 112.47 \\
\hline
\end{tabular}

Source: National Bureau of Statistics, "Nigeria Poverty Profile 2010".

In simple terms, 69 percent of the total population of the country was poor in 2010, and only 31 percent crossed the poverty line. No doubt, this poor population must have substantially increased between 2010 and the present year due to unabated unemployment rate, governmental and administrative corruption, and insecurity which has negatively affected entrepreneurial ventures. This is the society, in which the contemporary Nigerian church exists, experiencing the effects of this economic situation with other Nigerians, while expecting sustained improvements in future.

\section{Poverty within the Early Church}

It is within the above discussed great and multidimensional Roman territory that the early church existed with her 
peculiarities. It should be noted that the early church had both poor and wealthy members, with the poor being more in number. 1 Cor. 1:26 actually describes the Christians' economic condition, where not many were powerful and not many were well-born. Carey (2011) writes that Paul's words in the aforementioned verse "actually describe the population in general, in which not many did enjoy education, wealth, power or status. Similarly, Onwu (2007) thinks the "church was composed in the main of the despised, the poor and the humble" (p.243). It was this situation that necessitated charity. It was also probably because of the presence of poor people in the early church that the issue of poverty and wealth "was a major concern in earliest Christianity" (Onwu, 2007 p.236). Having made some studies about the social setting of the early church, Diara, (2008) wrote that "it appears that majority of the Christians were poor. Those who made rich offerings were rare, more numerous were those who had to be assisted by the community" (p.134).

Two words were used for poor in the New Testament- - Ptochos and Penes (plural Ptochoi and Penai, respectively). This has a strong implication about poverty in the early church. According to William (2006), in the early church, at least two degrees of poverty are recognized. By the use of two words for 'poor' in the New Testament sets forth this distinction." The two degrees can be likened to the situations defined with the terms-extreme and relative poverty. A Ptochos is one who is needy, a pauper, and dependent on others for support. ("Fribery Lexicon., Louw-Nida Lexicon; Thayer's Greek Lexicon; www.bible-history.com). The situation of the Ptochos is extreme poverty. This type of poverty means not having enough to survive (Corbett, n.d). A pauper is, according to Merriam Webster's Dictionary and Thesaurus, a person destitute of means except such as derived from charity (www.merriam-webster.com). By Ptochos William (2006) writes that "a condition is indicated of abject beggary, pauperism, such as that in which we find Lazarus who was laid at the gate of the rich man's palace, begging even the crumbs which fell from the table of the rich man". On the other hand, the situation of the Penes was not as bad as that of the Ptochos. The Penes was "a condition of living from hand to mouth, a bare and scant livelihood" (William, 2006 n.p). This condition was a situation of having just enough resources. This can be likened to the situation called relative poverty in modern terms. The Penes was not a pauper; he had means of livelihood, but was not in possession of many resources, but just enough for medium sustenance.

A similar but slightly different classification of poor Christians in the New Testament church was made by Okwueze (2003). According to him, "there are the indigent poor... There are those whose social deprivation and oppression by others in society brings them within the purview of the poor. Then there are the poor in spirit" (Okwueze, 2003 p.60). The indigent poor are those who lack material necessities of life in the ordinary sense. Those who belong to the second class experience inhibited social wellbeing because of the presence of some conditions such as slavery and imprisonment. He writes that, included in this second group are those who lack bodily wholesomeness or who are unhealthy and sick and therefore oppressed by one evil spirit or the other. These people can be said to be in poverty of health, as they experience abnormality in health. Both groups require supports, though in different forms. While the first class needs to be materially empowered to enable them take care of their basic needs, constituents of the second class need assistance and support not necessarily for their material (wealth) wellbeing but for their social wellbeing, by removing and liberating them from those conditions which inhibit their social wellbeing" (Okwueze, 2003).

The third class identified by Okwueze does not necessarily experience poverty (in modern sense of it). In other words, the constituents of this class were not classified as such because they had insufficient resources, income or because they could not get the necessities of life such as food, clothing and shelter. This is the class of those poor in spirit. "It refers to those who are humble- rather than require assistance and support; need to be emulated because as Jesus said, "Blessed are the poor in spirit, for theirs is the kingdom of heaven (Matt 5:3)" (Okwueze, 2003 p.60).In concise terms, it is right to say that not only was there poverty in the early church; a greater halve of the early Christians of the New Testament era consisted of people who by modern but relative economic analysis, would be classified as a society's poor constituents. Having stated earlier that the poor socio-economic situation of Nigeria has fuelled the wide acceptance and popularity of the prosperity gospel in the country, it is needful to ask the following- In the midst of that similarly poor economic situation of the empire and the early church, what was the church's approach to poverty and disposition towards the poor? Which specific ideologies did it have in relation to poverty? Expectedly, if there was any ideology about poverty, it would be well related to Jesus' teachings about poverty.

\section{Jesus and Poverty in the Synoptics}

This section examines Jesus' thoughts about poverty and relationship with the poor, as rendered in the Synoptics, so as to know whether he regarded poverty as ungodly, a curse or a dishonor unto the Creator. The gospels, particularly the Synoptics, provide substantial information on Jesus' teachings about poverty. The Synoptic Gospels, also called the Synoptics constitute the first three books of the New Testament- Matthew, Mark and Luke, which describe events in the life of Jesus in in the first century. It is worthy of note that "it has been observed that Mark is not concerned about the 
problem of poverty, as in Matthew and Luke (Mark 14:5,7)" (Onwu, 2007 p.7). The Gospel of Mathew defines the group called "poor", to include the blind, the lame, the oppressed, the hungry, the crowd, the heavy laden, and the lost sheep of the house of Israel (Onwu, 2007). The beatitude is also found in Mathew's gospel. Onwu writes that in the Beatitudes, the "emphasis is shifted from material sphere of (sic) the spiritual", showing that the evangelist is not largely interested in the problems of actual want (Onwu, 2007).

Evangelist Luke also shows interest in the poor, as Mathew, but in a higher height. He "begins Jesus' ministry by associating him with the social themes drawn from Isaiah but quoted in Luke 4:18-19" (Onwu, 2007 p.7). The groups contained in the passage are the poor, captives, the blind and oppressed. The subject of poverty and wealth received the highest treatment in the gospel of Luke. John Roth writes that evangelist Luke has "proportionally more materials than the other gospels dealing with the rich and the poor" (Roth, 1997 p.16). Walter Pilgrim also agrees that the subject of wealth and poverty is of a high importance to evangelist Luke, higher than other gospel writers, as part of Jesus' tradition and also the good news for the Christian communities who are to receive his writing (Pilgrim, 1981). Luke provided great information about the tradition of Jesus and poverty. He heavily focused on the presence and condition of the poor, the way in which God viewed those living in poverty, Jesus attitude, actions, and teachings involving the poor, and his warnings regarding their abuse and neglect (Brewer, 2009).

Notably, evangelist Luke is "particularly fond of exhortations to and examples of almsgiving" (Roth, n.d p.16). The Christians who have many resources are to help the poor; the needy believers are to be supported by those who have enough resources for such assistance. According to Shoemaker in Brewer, (2009), the gospel of Luke is mainly addressed to those who are actively far from poverty and categorized as wise, influential and of noble birth, all of which are considered wealthy in most cases. Perhaps "Luke's intent is to proclaim to those of wealthy status, the need to care for those who did not share their financial state" (Brewer, 2009 p.6). Giving to the poor, according to Jesus (in Luke), fetches for the giver, richness towards God. The parable of the rich fool explains this. The parable, contained in Luke 12:16-21, goes thus,

The ground of a certain rich man produced a good crop. He thought to himself what shall I do? I have no place to store my crops. Then he said, this is what I will do I will tear down my barns and build bigger ones, and there I will store all my grain and my goods. And I say to myself, you have plenty of good things laid up for many years. Take life easy; eat, drink and be merry, but God said to him, "you fool! This very night your life will be demanded from you. Then, who will get what you have prepared for yourself? This is how it will be with anyone who stores up things for himself but is not rich toward God.

It is expressed here that greed and refusal to give to the poor hinder one from becoming rich towards God. One could have wealth on earth, and enjoy greatly his wealth, but woe to one if one does not remember the poor and help them with the essential resources they need. Jesus makes the same teaching about concern for the poor with the story of Zacchaeus in Luke 19: 1-10. This paper agrees with Brewer (2009) that the story shows that Jesus, in part, associates salvation with the desire to give to the poor and aid others who are in need. In the story, Zacchaeus proclaimed "look, Lord! Here and now I give half of my possessions to the poor, and if I have cheated anybody out of nothing, I will pay back four times the amount" (v.8) and Jesus responded, "Today salvation has come to this house, because this man, too, is a son of Abraham. For the son of man came to seek and to save what was lost", (vv9-10). Similarly, in verse 33 of Luke 12, Jesus states, "sell your possessions and give to the poor. Provide purses for yourselves that will not wear out, a treasure in heaven that will not be exhausted, where no thief comes near and no moth destroys." This might be a confirmation that "by giving to the poor rather than hoarding one's wealth, the believer can further the course of the kingdom and becomes rich towards God" (Brewer, 2009 p.8). In other words, heavenly treasure can be obtained by giving money to the needy.

A passage of great significance in the Synoptics, which deals with Jesus' teaching about poverty is Luke 4:18-21. The significance of this passage is "perhaps the greatest in Luke's gospel, where the poor are specially mentioned" (Brewer, 2009 p.7). In the passage, Jesus had returned to his home town, Nazareth, after being in the wilderness for forty days. He quotes Isaiah 61:1-2, from the scroll of Isaiah, which states.

The spirit of the lord is on me, because he has anointed me to preach good news to the poor, he has sent me to proclaim freedom for the prisoners and recovery of sight for the blind, to release the oppressed, to proclaim the year of the Lord's favour (Brewer, 2009 p.7).

And Jesus tells the listeners, "today this scripture is fulfilled in your hearing", (v.20). This statement is the reader's first clue that God gives the poor the priority of the gospel message. It shows God's care and special interest in the poor. Notably, none of the teachings of Jesus related to poverty directly or indirectly implied that "since it is abnormal for a child 
of God to experience poverty, anyone found to be poor was under a satanic influence, and needs to be delivered of it." Jesus' teaching about poverty was mainly built on the idea that poverty is the lack of sufficient resources for human living, and this makes the poor to be needy and worthy of help and support. One who has enough resources to give to this group of people, therefore should not hesitate to do so, as it is an expression of goodwill and goodness. It is the unwise man who cares not about his spiritual state or fate, who does not give to the poor in the case of the availability of the resources required to do so. He who then does the opposite is wise, for he builds for himself treasures in heaven and not on earth, where the treasures cannot be eternal.

According to the Synoptics, Jesus did not say that because His Father is a rich God, none of His children should be poor. He rather once said that "the poor will always be with you." New Testament scholars have written a lot about this his statement. It could mean actually that conditions in the world are such that there will always be circumstances that lead to the experience of lack of sufficient resources by some members of a society and on the other hand, the availability of sufficient resources for some other members. It probably confirms that there will always be economic inequalities in the society. It should be marked, however, that his statement could not have been an attempt to institutionalize poverty. Poverty remains an undesirable state which no one deserves. It results from a multi-connection of factors, hence, almsgiving usually provides little or no lasting improvement for the poor.

\title{
10. The Early Church's Attitude towards Poverty And the Poor
}

That church's attitude towards poverty and the poor was perhaps built on the understanding that poverty was a state which puts one in need of support. Hence, it encouraged concern, support and care for the poor brethren in the church. The book of "Acts of the Apostles" is a significant biblical source of information about the early church and its activities. The first obvious instance in the book that relates to the church's practical attitude towards the poor is in chapter two. "At the end of the chapter", Luke "describes the new believing church- a familial type of community full of giving and sharing" (Brewer, 2009 p.11). Chapter 2, verses 44 and 45 state that "all the believers were together and had everything in common. Selling their possessions and goods, they gave to anyone as he had need. The early church did not neglect the poor and needy, and benefactors looked for ways to accommodate those in need, including the selling of property. This is further expressed in Acts 4:32-37, which says thus:

\begin{abstract}
All the believers were one in heart and mind. No one claimed that any of his possessions was his own, but they shared everything they had. With great power, the apostles continued to testify to the resurrection of the Lord Jesus, and much grace was upon them all. There were no needy persons among them, for from time to time those who owned lands or houses sold them, brought the money from the sales and put it at the apostles' feet, and it was distributed to anyone as he had need.
\end{abstract}

Acts 6:1, with the above passages, affirm a common fund of the Jerusalem community with the sole purpose of distributing money or food to the poor and widows. It is expressed in the three passages that the motive of charity is highly prevalent in the story of the early church (Kim, 1993). Below is a lengthy group of words in St. Justin the Martyr's first Apology for the Christian faith, containing not just the church's attitude towards the poor brethren, but implying how it was a part of their living to care for the needy in the second century.

\begin{abstract}
...the wealthy among us help the needy; and we always keep together; and for all things. Wherewith we are supplied, we bless the maker of all through His son Jesus Christ, and through the Holy Ghost. And on the day named after the sun, all, whether they live in the city or the country side, are gathered together in unity. Then the records of the apostles or the writings of the prophets are read for as long as there is time. When the reader has concluded, the presider in a discourse admonishes and invites us into the pattern of these good things. Then we all stand together and offer prayer. And, as we said before, when we have concluded our prayer, bread is set out to eat, together with wine and water. The presider likewise, offers up prayer and thanksgiving as much as he can, and the people sing out their assent saying the amen. There is a distribution of the things over which thanks have been said and each person participates, and these things are sent by the deacons to those who are not present. Those who are prosperous and who desire to do so give what they wish, according to each one's choice, and the collection is deposited with the presider. He aids orphans and widows, those who are in want through disease or through another cause, those who are in prison, and foreigners who are sojourning here. In short, the presider is a guardian to all those who are in need (Satoshi, 2010).
\end{abstract}

It is shown here that the key component of the disposition of the early church towards the poor is grant of support. Summarily, in the midst of a poor economic situation, the early church had no ideology about poverty and suffering which is similar to that of the contemporary prosperity preachers. Poverty was neither seen as a virtue nor an ungodly experience. 


\section{A Fact: Poverty is Beyond Faith+Positive Confession+Giving/Tithing}

One of the points of controversy in the prosperity preaching phenomenon in Nigeria is its simplistic view of poverty. While this paper may be unable to successfully disprove the importance of a religious approach to economic problem solving, the paper maintains that a simplistic view of poverty and the problem of wants which is found in the prosperity gospel is hardly reasonable. A religious approach may be beneficial because experience has shown that in Nigeria, individuals can influence the socio-economic and physical conditions of fellow humans through traditional religious means However, it is factual that only a minuscule and ignoble percentage of poor conditions resulted from this manipulation. Poverty in Nigeria, as in many other countries, has political and economic causes, hence, while a spiritual approach to it is being adopted, there is need to be reminded of the wideness of the problem.

It is proper to group the ways of measuring and defining poverty, which various scholars have used. The first is in terms of human capital, where the earning potential of a person is used. By this, "a person or people", writes Corbett, "with relatively high earning potentials is/are not poor because they should be able to easily find work" (Corbett, 2009 n.p). By this measure, the possession of work skills is what determines whether one is poor or not. The second way is using quality of life measures such as the opportunity to freely choose professions and life style, the right to receive a full and free education, and freedom from political oppression (Corbett, 2009). It is based on the quality of life that McCelland (2000) defines poverty as "... where people have unreasonably low living standards compared with others; cannot afford to buy necessities... and experience real deprivation and hardship in everyday life". In the same line also, World Bank conceptualizes poverty as "pronounced deprivation in wellbeing" where wellbeing can be measured by an individual's possession of income, health, nutrition, education, assets, housing and certain rights in a society such as freedom of speech (World Bank, 2005 p.6).

Thirdly, poverty can be measured and defined from a human rights dimension. It is from this perspective that Arbour said that "one may say that a person living in poverty is one for whom a number of human rights remain unfulfilled-such as the rights to food, health, political participation" (Arbour, 2012 p.2). To him, poverty describes a web of connections and deprivations which impact on people's ability to access their civil, cultural, economic, political and social rights. He puts more succinctly that:

\footnotetext{
poverty can be described as the denial of a person's right to a range of basic capabilities. Such as the capability to be adequately nourished, to live in good health and to take part in decision making processes and in the social cultural life of the community (Arbour, 2012 p.2).
}

This means that capability failure is a major feature of poverty. It consists in non-fulfillment of one's right to a range of capabilities. Poverty is "about the denial of opportunities and choices that are widely regarded as essential to lead a long, healthy, creative life and to enjoy a decent standard of living, freedom, dignity, self-esteem and the respect of others" (http://cybershoolbus.un.org).

The meaning of poverty that has gained wide international acceptance, has changed and improved from time to time. In the early days of the United Nations, "poverty line" was used to define poverty. "Poverty was measured in terms of the ability to meet a minimum number of calories or to have a minimum level of income to satisfy needs" (http://cybershoolbus.un.org). This minimum level was specified by the "poverty line and the poor constituted those whose incomes or calorie intake are less than this line. In other words, possession of income was used to identify the poor. The commonly used $\$ 1$ and $\$ 2$ per day measure (purchasing power equivalent to $\$ 1$ or $\$ 2$ in the United States in 1993) is based on income level.

In the 1980s and 1990s, the concept underwent further change by considering non-monetary aspects, as it was mainly defined in financial terms. The non-pecuniary characteristics which were considered included factors such as social relations, powerlessness, vulnerability, security. Having been inspired by the work of Amartya Sen, a world famous economist who won the Noble prize for economics in 1999, the United Nations Development Programme (UNDP) later "introduced measures for progress and for deprivation that focus on poverty from a human development perspective. It now views poverty as a denial of choices and opportunities for living a tolerable life" (http://cybershoolbus.un.org).

One notable involvement in poverty is that it causes factors which widely impact on human life and these factors as well lead to the presence of poverty. According to David (2008) overall poverty takes various forms, including lack of income and productive resources to ensure sustainable livelihoods; hunger and malnutrition, ill health, limited or lack of access to education and other basic services; increased morbidity and mortality from illness, homelessness and inadequate housing, unsafe environments and social discrimination and exclusion, lack of participation in decisionmaking and in civil, special and cultural life (David, 2008). All the above factors can result from, or even cause poverty. 
Corbett writes that "in most cases, the causes and effects of poverty interact, so that what makes people poor also creates conditions that keep them poor" (Corbett, 2009 n.p). Primary factors that may lead to poverty, according to him, include overpopulation, unequal distribution of resources in an economy, inability to meet high standards of living and costs of living, inadequate education and employment opportunities, environmental degradation, certain economic and demographic trends and welfare incentives. It is interesting to identify that some of the above factors given by Corbett as primary causes of poverty are direct and immediate elements of poverty. For instance, inability to meet high standards of living and costs of living. This shows how much the causes and effects of poverty interact.

In Nigeria, widespread poverty remains a key socio economic problem of the country, in spite of the many natural and human resources within. This has been attributed to many factors. Otu et al, attribute it to corruption, mismanagement of resources, unemployment, lack of manpower, low standard in the educational system, low income distribution, low gross domestic or national product (GDP, GNP), rural poverty, brain, marginalization, deprivation and human degradation, poor performance of sustainable policies and programmes and bad leadership (Otu et al 2011). Implied in their study and many other studies is that poverty in Nigeria is not caused by any single factor, rather its presence is as a result of a web of factors, interconnection of factors. There is no one cause of poverty. It is a mixture of several factors that leads to poverty. Ajakaiye and Adeyeye provided somewhat different causes of poverty in Nigeria, viz: low or negative economic growth, inappropriate macroeconomic policies, deficiencies in the labour market resulting in limited job growth, low productivity and low wages in the informal sector, a lag in human resource development, increase in crime and violence, environmental degradation, retrenchment of workers, fall in the real value of safety nets and changes in family structures (Ajakaiye and Adeyeye, n.d). Agreeably, laziness also contributes to the presence of poverty. By laziness is meant the character of being disinclined to activity or unwilling, because of mild dislike or disapproval, to be active, or not being energetic or vigorous. It is one of the causes of poverty in Nigeria.

Governance also substantially influences the presence of poverty in a society, either positively or negatively. Connected with public governance in Nigeria are factors as corruption, poor accountability, mismanagement of state's resources, lack of transparency in resource allocation, selfishness of public leaders, weak programme implementations and monitoring, and ineffectiveness of programmes and policies aimed at poverty reduction and the citizens' welfare. Below is a summary of the causes of poverty in Nigeria, by the Socio Economic Profile of Nigeria in 1996 (Aluko, 2003).

1. Inadequate access to employment opportunities for the poor. The stunted growth of economic activities or growth often causes this with labour saving device;

2. Lack of inadequate access to assets such as land and capital by the poor. This is often attributed to the absence of land reform and minimal opportunities for small scale credit;

3. Inadequate access to the means of fostering rural development in poor regions; the preference for high potential areas and the strong urban bias in the design of development programmes is often assumed to be its primary cause;

4. Inadequate access to market for the goods and service that the poor can sell; this is caused by the remote geographical location or other factors;

5. Inadequate access to education, health, sanitation and water services. This emanates from inequitable social service delivery, which consequently results in the inability of the poor to live a healthy and active life and take full advantage of employment opportunities; The destruction of the natural resource endowments, which has led to reduced productivity of agriculture, forestry and fisheries. This often resulted from the desperate survival strategies of the poor as well as inadequate and ineffective public policy on natural resource management.

6. The inadequate access to assistance by those who are the victims of transitory poverty such as drought, floods, pests and war. This is brought about by lack of well conceived strategies and resources; and

7. Inadequate involvement of the poor in the design of development programmes. This is often exacerbated by the non involvement of the representatives of the poor communities or beneficiaries in the discussion, preparation, design and implementation of programmes that will affect them.

It is important to point out that a distinction is being made between extreme poverty and relative or moderate poverty. Adam smith, a classical economist, was probably referring to extreme poverty when he defined poverty as "a lack of those necessities that the custom of the country renders indecent for creditable people, even of the lowest order, to be without" (www.shillington.ca). Extreme poverty, as the name implies, is the most unbearable form of poverty. According to Corbett, "extreme poverty in developing nations, as defined by international organizations, means having a household income of less than $\$ 1$ per day" (Corbett, 2009 n.p). It means not having enough to survive. It is different from relative poverty which is "the condition of having fewer resources or less income than others within a society or country, or compared to worldwide averages" (Corbett, 2009 n.p). It is a situation whereby people can afford basic needs or necessities, but cannot be said to be rich in comparison with others. The following is a tabular presentation of a study by 
the National Bureau of Statistics (NBS) which differentiates the moderately/relatively poor Nigerians from the extremely poor, between 1980 and 2010 .

Table 2:Showing Relative Poverty: Non-poor, Moderate Poor and the Extremely poor ,1980-2010

$\begin{array}{cccc}\text { Year } & \text { Non-poor } & \text { Moderately poor } & \text { Extremely poor } \\ 1980 & 72.8 & 21.0 & 6.2 \\ 1985 & 53.7 & 34.2 & 12.1 \\ 1992 & 57.3 & 28.9 & 13.9 \\ 1996 & 34.4 & 36.3 & 29.3 \\ 2004 & 43.3 & 32.4 & 22.0 \\ 2010 & 31.0 & 30.3 & 38.7\end{array}$

Source: National Bureau of Statistics, "Nigeria Poverty Profile 2010".

Succinctly, economic prosperity can only be sustained by means broader than the spiritual approach adopted by prosperity preaching. This spiritual/religious approach is yet controversial among theologians, as payment of tithes-a major constituent of this approach, may not be right.

\section{Results and Conclusion}

Having done the above study, one can identify the differences between the notion and attitude of the early church and that of the present Pentecostal church, regarding poverty and prosperity. Below is a list of statements of result.

(i) There Was No Prosperity Ideology in the Early Church.

(ii) Money Was Not a Priority, Righteousness Was.

A negative effect of this preaching is connected to the significance it attaches to money. Prosperity preaching heightens money consciousness in the minds of the followers. The Prosperity Preachers maintain that poverty and suffering are not to be experienced by a "child of God". Followers are then to perform various activities to come out of these problems. Tithing has been found to be a common practice promoted by the preachers. This teaching leads to deviance, especially among youths, either in form of kidnapping, armed robbery and so on.

\section{Acknowledgements}

The authors declare that they have no financial or personal relationship(s) that might have inappropriately influenced them in writing this article.

\section{References}

Adeboye, E. A (2014). Behold He cometh!: Are you prepared? Maryland, USA: Christian Living Books Inc.

Ajakaiye, D. $\mathrm{O}$ and Adeyeye, V. A (n.d). Concepts, measurement and causes of poverty CBN Economic and Financial Review, 39, 4.

Aluko, M. A. O (2003). Strategies for poverty reduction in Nigeria" Journal of Social Sciences, 7, 4.

Arbour, L (2012). Principles and guidelines for a human rights approach to poverty reduction strategies. A publication of the office of the United Nations High Commissioner for Human Rights, Geneva, Switzerland. Accessed on 23/3/2016 from www.ohchr.org/ documents/publications/povertystrategiegen.pdf. p.2.

Brewer, R. S (2009). Wealth and poverty in Luke's gospel and Acts: A challenge to the Christian Church. Journal for Pentecostal Ministry, 6.

Carey, G (2011). Were the first christians rich or poor?Accessed on 17/08/2015 from www.huffingtonPost.com/blackberry/p.html?u944019

Celestina, O. I (2007). Pentecostalism in the Nigerian society: A therapy or a delusion. in G.N. Amuluche (ed.) The New Religious Movements: Pentecostalism in Perspective, Benin City: Ava publishers.

Corbett, T. J (2008). Poverty Microsoft (R) Encarta (R) 2009(DVD) Redmond, WA: Microsoft Corporation.

David, G (2008). Indicators of poverty and hunger. A paper presented in Expert Group Meeting on Youth Development Indicators, United Nations Headquarters, New York, between 12-14 December, 2008. Accessed on 21/3/2016 from www.un.org/esa/socder/ungin/ documents/ydiDavidGordon-poverty.pdf.

Diara, B. C. D (2011). Anointing makes the difference: The Nigerian pentecostal experience. Journal of Bible Exposition.

Diara, B. C. D (2008). The early church and economic empowerment program. Nsukka Journal of Religious studies 2, 1.

Emeka, P (2002). The Benson Idahosa factor in Nigerian pentecostalism" (PhD Diss.,University of Nigeria, Nsukka, 2002). 
Folarin, G. O (2006) The prosperity gospel in Nigeria: A re-examination of the concept, its impact and an evaluation. African Journal of Biblical Studies, 23, 2.

Guthrie, G. H (2010). The socioeconomic background of the New Testament. USA: LifeWay Press.

Ituma, E. A (2011). Data analysis/visualization in social sciences: Current challenges and trends in religious studies. International Journal of Research In Arts And Social Sciences, 3.

James, D. T (n.d). The roman world of Jesus: An overview. Accessed on 22/3/2016 from htt://class-pages.uncc.edu

Joyce, G (1908). The church. The Catholic Encyclopedia, 3 .New York: Robert Appleton Company. Accessed 22/11/2014, www.neadvent.org/cathen/037449.htm.

Kim, K (1993). Stewardship and almsgiving: Luke's Theology of wealth. Tyndale Bulletin, 44, 2.

Lioy, D (2007). The heart of the prosperity gospel: self or the savior? Conspectus 4, 1.

Margaret, A and Robin, O (2006). Poverty in the Roman world. Cambridge: Cambridge University Press.

National Bureau of Statistics (2010) Nigeria poverty profile. Accessed 12/08/2015 www.Nigerianstat.gov.ng/pdfuploads/Nigeria poverty profile 2010.pdf

Okwueze, M. I (2003). Ethics, religion and society: Biblical, traditional and contemporary perspectives. Nsukka: Prize Publishers.

Onimttawo, J. A (2007). Catholic church and pentecostalism: History of a relationship. In G. N. Amuluche (ed.) The New Religious Movements. Pentecostalism in Perspective. Benin City: Ava publishers.

Onwu, E. N (2004). Basic issues in the close of the New Testament era. Nsukka: Great AP Express Publishers.

Onwu, E. N (2007). Poverty and prosperity in Nigerian pentecostal theology: A New Testament critique. Journal of New Testament Research.

Otu, J.E., Eja, E. I., Eko, J. A., and Josephat, E. O (2011). Analysis of poverty indices in underdeveloped countries: Nigeria scenario. Mediterranean Journal of Social Sciences, 2, 2.

Oyedepo, D. O (1992). Towards excellence in life and ministry, Agege: Dominion House.

Pauper. Merriam Webster's Dictionary and Thesaurus. Accessed on 17/08/2015 from www.merriam-webster.com

Pilgrim, W (1981). Good news to the poor: Wealth and poverty in Luke-Acts. Minneapolis: Augsburg Publishing House.

Poverty: A short History (n.d). Accessed on 23/2/2016 from www.shillington.ca/poverty/povertyashorthistory.pdf.

Price, C (2008). Church (Movement) Microsoft @ Encarta ® 2009 [DVD]. (Redmond, WA: Microsoft Corporation.

Roth, S. J (1997). The blind, lame and the poor: Character types in Luke-Acts. England: Sheffield Academic Press.

Satoshi, T (2010) Poverty and charity in early christianity: Some preliminary observations. Mediterranean World, 20.

Tony, L (1994). The new community of the church. A Lion Handbook: The World's Religions. Oxford: Lion publishing.

Ukah, A (2007). African christianities: Features, promises and problems. Institut fur Ethnologie und Afrikastudien, 79.

William, E (2006). Poverty. ISBE Encyclopedia, in Bible works, version 7.0.0129.

World Bank Institute (2005). Introduction to poverty analysis. Poverty Manual, A11, JH Revision. 